\title{
Snorri Sturluson as a historian of religions: The credibility of the descriptions of pre-Christian cultic leadership and rituals in Hákonar saga góda
}

\begin{abstract}
This study investigates the credibility of the descriptions of pre-Christian cultic leadership and rituals in Snorri Sturluson's Hákonar saga góða. The perspective is one taken from the study of the history of religions. By using a comparative method, one which combines source criticism and philology, ancient ideas may be detected even within Snorri's reconstruction. Scholars have interpreted these ideas by setting them in a wider source context. Here it is argued that several ideas in Snorri's description in Hákonar saga góða may be attested in sources which are closer to the Viking Age, such as Skaldic poetry, runic inscriptions and archaeological finds. For instance, the idea that political leaders such as kings and earls were involved in public cults may be one based on ancient traditions. Snorri, too, was probably on firm ground when he stated that the rulers (at least the king) were supposed to take part in certain rituals while attending sacrificial feasts: rituals such as drinking ceremonies and meal customs perhaps such as the eating of horseflesh. That these ceremonies sometimes took place in some kind of cultic building or banqueting hall, such as described by Snorri, seems also likely. It is emphasized, however, that some elements in his text must be seen as suspect, as Olaf Olsen, Ernst Walter and Klaus Düwel have noted. These elements include certain religious terms, as well as the act of making the sign of the hammer over the horn. Generally, however, it is argued that Hákonar saga góða, if treated with care, may still be used as a source for pre-Christian religion.
\end{abstract}

The mythical and historical writings of Snorri Sturluson (1179-1241) have been debated in research for more than one hundred years. Snorri's texts have sometimes been felt to be almost useless when reconstructing ancient Scandinavian religion and Viking Age history. ${ }^{1}$ This type of source-critical approach has deep roots in the study of Old Norse philology and religion as well as in the general study of history. ${ }^{2}$ One prominent representative for this skeptical position was the German scholar Walter Baetke. Some of his ideas have been instrumental in establishing the modern treatment of Snorri's texts. Baetke argued, for instance, that Snorri revised the old mythical traditions in accordance with learned medieval models and his own imagi-

1 See e.g. Olsen 1966; Düwel 1985.

2 See e.g. Bugge 1881-89; Mogk 1923 and 1932; L. Weibull 1948; C. Weibull 1964. 
nation. For example, Snorri frequently used medieval euhemerism when describing ancient myths. This method was a common feature of ecclesiastic apologetics, where the pagan deities were considered as ancient human rulers and thus not 'real gods'. Because of this approach and other rewritings of the traditions, Baetke considered Snorri's descriptions of myth to be unreliable when reconstructing pagan religion. ${ }^{3}$ A similar stand was also taken by the Norwegian philologist Anne Holtsmark. ${ }^{4}$ This critical attitude against Snorri is also reflected in more recent research concerning his historical writing in Heimskringla. It has been stated that Snorri was "not at all reluctant to adapt his sources as he sees fit and even write whole new chapters of his own in order [...] to clarify connections and make his narrative more alive". ${ }^{5}$

Even if Snorri's writings have not satisfied the stern criteria of source criticism, several scholars have felt they should not be completely discarded as sources of knowledge for Viking Age religion and culture. ${ }^{6}$ Some of them incorporate oral traditions which may reach back to the Viking Age. Some traditions have probably been reworked by Snorri and other medieval scribes, by means of medieval thinking and artistic enthusiasm. This reworking is no reason to dismiss them altogether. Snorri and the medieval writers probably had access to more direct sources than the modern historian has, and most likely they were better suited to interpret them when making their historical reconstructions. ${ }^{7}$

The present paper will investigate the credibility of the descriptions of pre-Christian cultic leadership and rituals in Snorri’s Hákonar saga góða. My perspective here is taken from the history of religions. By using a comparative method which combines source criticism and philology, I will try to detect ancient notions in Snorri's reconstruction. These notions can be interpreted by setting them in a wider context of sources. In these comparisons mostly direct sources will be applied, that is, skaldic poetry, runic inscriptions, and especially archaeological finds. When such comparison is not possible (due to scarcity of direct sources), the absence of similar ideas and customs in contemporary Christian culture is taken as support for the reliability of medieval statements on ancient Scandinavian tradition. Other independent (and

3 Baetke 1950, 1951 and 1964.

4 Holtsmark 1964.

5 Jónas Kristjánsson 1988, p. 175. Cf. Vésteinn Ólason 1998, p. 59.

6 See e.g. Dumézil 1948; Ström 1975; Meulengracht Sørensen 1991; Hultgård 1993; Dillmann 1997 and 2008; Steinsland 2000 and 2005; Schjødt 2008; Hedeager 2011.

7 Preben Meulengracht Sørensen made the following observations when considering Snorri's narrative about Hákon the Good and sacrifices in Trøndelag: "History is not the data extracted from the sources, but the syntheses created out of the data, and historical writings are not the reestablishment of past reality, but the creation of historical probabilities. In this perspective the medieval narrative historiographic texts should be considered primary sources, since their authors had better access to authentic sources than the modern historian and were presumably better suited to interpret them" (Meulengracht Sørensen 1991, p. 244). 
indirect) sources are also useful in this investigation, such as Icelandic prose which is older than Hákonar saga góða and some ecclesiastical texts in Latin.

\section{The text}

Hákonar saga góða is a part of Snorri's Heimskringla. Heimskringla is thought to have been written about 1230, and it is preserved in three major witnesses: (1) Kringla: AM 35 fol. is a copy of Kringla made by Ásgeirr Jónsson c. 1700, and provided with corrections made by Árni Magnusson. (2) Codex Frisianus: AM 45 fol., was written by an Icelander c. 1325. (3) Jofraskinna: AM 37 fol. is the oldest and best copy of Jofraskinna, unfortunately defective, made by Bishop Jens Nielssön c. 1567-68 (J1). AM 38 fol. is a copy of Jǫraskinna made by Ásgeirr Jónsson 1698 (J2). A good text critical edition was published by Bjarni Aðalbjarnarson in Íslenzk fornrit, and it will be used in present study.

In one passage of Hákonar saga góða, chapter 13 to 18, the text describes ceremonial feasts in Viking Age Trøndelag. Snorri writes thus (in ch. 14):

Sigurðr Hlaðajarl var inn mesti blótmaðr, ok svá var Hákon, faðir hans. Helt Sigurðr jarl upp blótveizlum ollum af hendi konungs par í Prondalogum. Pat var forn siðr, pá er blót skyldi vera, at allir bondr skyldu par koma, sem hof var, ok flytja pannug fong sin, bau er peir skyldu hafa, meðan veizlan stód. At veizlu peiri skyldu allir menn ǫl eiga. Par var ok drepinn alls konar smali ok svá hross, en blóð pat allt, er par kom af, pá var kallat hlaut, ok hlautbollar pat, er blóð pat stóð í, ok hlautteinar, pat var svá gọt sem stǫklar, með pví skyldi rjóða stallana ǫllu saman ok svá veggi hofsins útan ok innan ok svá støkkva á mennina, en slátr skyldi sjóða til mannfagnaðar. Eldar skyldu vera á miðju gólfi i hofinu ok par katlar yfir. Skyldi full um eld bera, en sá, er gerði veizluna ok hofðingi var, pá skyldi hann signa fullit ok allan blótmatinn, skyldi fyrst Óðins full - skyldi pat drekka til sigrs ok ríkis konungi sínum - en síðan Njarðar full ok Freys full til árs ok friðar. Pá var morgum monnum títt at drekka par næst bragafull. Menn drukku ok full frænda sinna, peira er heygðir hofðu verit, ok vấru pat minni kọlluð. ${ }^{8}$

8 Heimskringla (Bjarni Aðalbjarnarson 1941-51), 1, p. 167 f. Hollander translated it (and here somewhat modified): 'Sigurðr Hlaðajarl, was most ardent heathen worshipper, as had been Hákon his father. Sigurðr jarl maintained all sacrificial feasts there in Trøndelag on the king's behalf. It was ancient custom, that when sacrifice was to be made, all farmers were to come to the hof and bring along with them the food needed while the feast lasted. At this feast all were to take part in the drinking of ale. Also all kinds of livestock were killed in connection with it, horses also; and all the blood from them was called hlaut, and hlautbolli, the vessel holding that blood; and hlautteinar, the sacrificial twigs. These were fashioned like sprinklers, and with them were to be smeared all over with blood the stallar and also the walls of the hof, within and without, and likewise the men present were to be sprinkled with blood. But the meat of the animals was to be boiled and to serve as food at the banquet. Fires were to be lighted in the middle of the hof floor, and kettles hung over them. The sacrificial beaker was to be borne around the fire, and he who made the feast and was chieftain, was to bless the beaker as well as all the sacrificial meat. Óðinn's toast was to be drunk first - that was for victory 
Snorri also states that Earl Sigurðr was generous and that he once made a great sacrificial feast at Hlaðir, defraying all expenses himself. He supports his narrative with a stanza brought from Kórmakr Qgmundarson's Sigurðardrápa (960 AD) (see the text below) where Earl Sigurðr is praised.

In the frame story Snorri recounts how King Hákon the Good had a Christian upbringing in England. He was unenthusiastic about the pagan cult in Norway, and wanted to convert the Norwegians gently. The farmers of Trøndelag opposed him and at the Frostaping required the king to take part in the traditional rituals: "The farmers said that it was their wish that the king should make sacrifice to procure for them good crops and peace, as his father had done". ${ }^{9}$ Later, during the fall, the king came to the annual sacrificial feast at Hlaðir. Snorri states thus (in ch. 17):

Um haustit at vetri ${ }^{10}$ var blótveizla á Hlǫum, ok sótti par til konungr. Hann hafði jafnan fyrr verit vanr, ef hann var staddr par, er blót váru, at matask í litlu húsi með fá menn. En bœndr tǫlðu at pví, er hann sat eigi í hásæti sínu, pá er mestr var mannfagnaðr. Sagði jarl, at hann skyldi eigi pá svá gera. Var ok svá, at konungr sat i hásæti sínu. En er it fyrsta full var skenkt, pá mælti Sigurðr jarl fyrir ok signaði Óðni ok drakk af horninu til konungs. Konungr tók við ok gerði krossmark yfir. Pá mælti Kárr af Grýtingi; 'Hví ferr konungrinn nú svá? Vill hann enn eigi blóta?' Sigurðr jarl svarar: 'Konungr gerir svá sem peir allir, er trúa á mátt sinn ok megin, ok signa full sitt Pór. Hann gerði hamarsmark yfir, ádr hann drakk.' Var pá kyrrt um kveldit. Eptir um daginn, er menn gengu til borða, pá pustu bœndr at konungi, segðu, at hann skyldi eta pá hrossaslátr. Konungr vildi pat fyrir engan mun. Pá báðu peir hann drekka soðit. Hann vildi pat eigi. Pá báðu beir hann eta flotit. Hann vildi pat ok eigi, ok var pá við atgongu. Sigurðr jarl segir, at hann vildi sætta pá, ok bað pá hætta storminum, ok bað hann konung gína yfir ketilhodduna, er soðreykinn hafði lagt upp af hrossaslátrinu, ok var smjor haddan. Pá gékk konungr til ok brá líndúk um hǫdduna ok gein yfir ok gékk síðan til hásætis, ok líkaði hvárigum vel. ${ }^{11}$

and power to the king - then Njorðr's and Freyr's, for good harvest and peace. Following that many used to drink a bragi-beaker. Men drank toasts also in memory of departed kinsfolk - that was called minni.'

9 Bœendr segja, at peir vilja, at konungr blóti til árs peim ok friðar, svá sem faðir hans gerði (Heimskringla (Bjarni Aðalbjarnarson 1941-51), 1, p. 170).

10 So has K; F and J have vetrnóttum.

11 Heimskringla (Bjarni Aðalbjarnarson 1941-51), 1, pp. 171 f. Hollander’s translation: 'In the fall, at the beginning of winter, there was a sacrificial feast at Hlaðir and the king attended it. Before that, if present at a place where heathen sacrifice was made, he accustomed to eat in a little house apart, in the company of few men. But the farmers remarked about it that he did not occupy his high-seat when there was the best cheer among the people. The earl told him that he should not do that; and so it came that the king occupied his high-seat [on this occasion]. But when the first beaker was served, Sigurðr jarl proposed a toast, dedicating the horn to Óðinn, and drank to the king. The king took the horn from him and made the sign of the cross over it. Then Kárr of Grýtingi said 'Why does the king do that? Doesn't he want to drink of the sacrificial beaker?' Sigurðr jarl made answer, 'The king does that all do who believe in their own might and strength, and dedicated his beaker to Pórr. He made the sign of the hammer over it before drinking.' People said no more about it that evening. Next day when people had seated themselves at the table, the farmers thronged about the king, saying that now he must eat the horse meat. That, the king would not do under any condition. Then they asked 
Later, at Yule, the king visited Mæri(n), where the chieftains and farmers held ceremonial meals. On this occasion he was forced to eat a few pieces of horse-liver. He also drank the toasts without making the sign of the cross.

\section{The criticism and previous scholarly discussions}

Snorri's text has been debated during the last decades. Olaf Olsen, for instance, was very sceptical to Snorri's description of pagan cult. ${ }^{12}$ Indeed he accepted Snorri's statement that pre-Christian ceremonial meals and drinking feasts were celebrated indoors, however, details in Snorri's account, such as the description of the hof-building, the cultic objects, and the ritual actions that took place there, were regarded as uncertain. Also Ernst Walter felt that Snorri's description was suspicious, especially parts of the ceremonial drinking in chapter $17{ }^{13}$ He pointed out that the Old Norse word signa meaning 'dedicate, bless' is a loan word from the ChristianLatin concept, signare (signo), that is, 'to make a sign'. Signa appears here in connection with krossmark ('sign of a cross') and hamarsmark ('sign of the hammer'). The Old Norse krossmark is derived from the Christian expression signum crucis, while hamarsmark appears for the first time in Hákonar saga góða and thus cannot be accepted as authentically pre-Christian. The expressions gerði krossmark yfir and gerði hamarsmark yfir seem therefore to be derived from the Christian signum crucis facere.

With no doubt Walter's argument seems plausible. The expression hamarsmark may very well be a construction made by Snorri or some other medieval writers. Whether the loan-word signa indicates that the content of the text is late and not built on pre-Christian notions is uncertain. This term appears in eddic and skaldic poetry, as well as in an $11^{\text {th }}$ century runic inscription from Uppland, namely U 942. The runologist Henrik Williams therefore argues that it is possible that this word was borrowed already before conversion and thus may have been incorporated into the pagan religious terminology. ${ }^{14}$

\footnotetext{
him to drink the broth from it. He would not do that, either, and they came near to make an attack on him. Sigurðr jarl said he would help them come to an agreement, asking them to cease their tumult; and he asked the king to gape with his mouth over the handle of the kettle on which the smoke of the broth from the horse meat had settled, so that the handle was greasy from it. Then the king went up to it and put a linen cloth over the handle, and gaped with his mouth over it. Then he went back to his high-seat, and neither party was satisfied with that.'

12 See Olsen 1966, pp. 59 ff.

13 Walter 1966.

14 Williams 1996, p. 79.
} 
Also Klaus Düwel argued in the same vein as Olsen and Walter in his learned and impressive study "Das Opferfest von Lade". ${ }^{15}$ The purpose of his study was to expose the structure of Snorri's text and the storytelling. He also scrutinized the semantic development of certain religious terms, such as the concepts hlautteinn and hlaut, and finally he also investigated the sources Snorri may have used when describing the pre-Christian cult. In his conclusion, Düwel stated that the actions connected with the sacrifices at Hlaðir had no Germanic origin, that is, that Snorri had no pre-Christian sources for these rituals. Rather, when describing how blood was sprinkled on the altar in the hof there, Snorri modelled his account on ancient Jewish rituals described in Exodus 24, which was translated to Old Norse in the text called Stjórn. During the early Middle Ages, the sacrificial rituals of the Old Testament were considered pagan, and pagan religion was thought to be the same in all places: this led Snorri to use this material in his account of the ancient cult in Trøndelag. Düwel also argued that Snorri projected customs common in medieval guilds back to heathen times, for instance, the ceremonial minni-drinking. In his analyses of the religious terminology Düwel concluded that in most cases Snorri either misunderstood these concepts or mixed them up with Christian ideas with no basis in pre-Christian culture, such as the term minni. In the final parts, Düwel also stated that Snorri applied a method called interpretatio Christiana, when describing pagan religion in Heimskringla. Snorri's purpose was actually not to describe the pagan cult, but to show how violent the missions of the Norwegian royal power had been in contrast to the situation in Iceland. Düwel concluded therefore that the description of sacrificial rituals in Hákonar saga góða is not reliable and thus cannot be used as a source for pre-Christian religion.

In a general sense Olsen's, Walter's, and Düwel's criticism has been well-founded and good for the research on ancient Scandinavian religion. Düwel was, for instance most likely right in his conclusions about the terms hlautteinn and hlaut. However, sometimes this source criticism has been somewhat simplified and without nuances, especially when stating that Snorri had no access to ancient sources on these rituals. Scholars, such as Preben Meulengracht Sørensen, Anders Hultgård and FrançoisXavier Dillmann have all been given, in my view, more balanced accounts. ${ }^{16}$ They agreed with Olsen and Düwel that some of the details in Snorri's reconstruction cannot be verified and thus do not produce a trustful image of the pagan cult, as previous historians of religions sometimes claimed. They also agreed with Düwel that this text must be related to Snorri's Christian view of history. However, this does not mean that Snorri was not at pains to make a trustfully image of the pre-Christian sacrificial cult in a general sense. That some essential religious terms not with certainty

15 Düwel 1985.

16 See e.g. Meulengracht Sørensen 1991; Hultgård 1993 and 1996; Dillmann 1997. 
can be deduced to heathen times is not a sufficient argument for concluding that the phenomena they designated not existed in the old religion. ${ }^{17}$

There are also elements in Snorri's description which may be ancient. Anders Hultgård, for instance, has in several important publications been giving strong and well-founded arguments in support for a pre-Christian origin of the formula ár ok friðr which is mentioned in Snorri's text. ${ }^{18}$ In line with Hultgård I will argue that some other themes in Snorri's account may be built on ancient traditions, more precisely some aspects which concerns cultic leadership in Trøndelag. These themes have been discussed in previous research in connection to Hákonar saga góða, by Preben Meulengracht Sørensen. ${ }^{19}$ But opposite to him I will emphasize that Snorri's text (and other sources) indicates the notion that the ruler (i.e. the king or the earl) as well as the chieftains had important cultic roles and was an important ritual link to the gods when attending these ceremonies. The secular and religious leadership was one and the same in all levels of the society. My purpose here is to illuminate these notions with materials, which not have had enough attention in this debate. But first I will put focus on Snorri's sources for the description of cultic leadership and rituals in Trøndelag. ${ }^{20}$

\section{Snorri's sources}

In Hákonar saga góða Snorri explicitly states that Sigurðr Hlaðajarl, “was most ardent worshipper" (var inn mesti blótmaðr) and that he "maintained all sacrificial feasts there in Trøndelag on the king's behalf” (helt Sigurðr jarl upp blótveizlum ollum af hendi konungs par i Prœendalogum). Snorri also states that Earl Sigurðr sometimes defrayed all expenses himself for them. The idea that the earl played important roles in the religious sphere and commissioned the sacrifices may, for instance, be sup-

17 Cf. Meulengrach Sørensen 1991, p. 239; Dillmann 1997, pp. 57 f.

18 See Hultgård 1993, 2003 and 2007.

19 Meulengracht Sørensen states in his English summary thus: "The cult activities seem to have been organized by those in power on different social levels, yeomen and chieftains. The king had no exceptional authority in terms of religion, since he had no exceptional power. He had a particularly important relationship to the gods, and a particular responsibility, but he had no indispensable function in the cult. The landowners were in charge of the cult, and the king took part in their local cult-feasts. The religious leadership was in the hands of the yeomen as long as the power belonged to them [...]" (Meulengracht Sørensen 1991, p. 244). I agree with Meulengracht Sørensen that this text and other written sources indicate that the secular and religious leadership was one and the same, however, in my opinion the king and the earl as well as the chieftains cared for the public cult and played important ritual roles during the sacrificial feasts.

20 For a more thorough investigation of Snorri's sources to the present passage, see Jón Hnefill Aðalsteinsson 1998, pp. 57-80. 
ported by the contemporary skaldic poem Sigurðardrápa (960 AD), which was quoted by Snorri and thus must be regarded as one of his major sources for the current passage.
Hafit maðr ask né eskis
afspring með sér pingat
fésæranda at fœra
fats. Véltu goð Pjaza.
Hver myni vés við valdi
vægja kind of bægjask,
pvít für-Rogni fagnar
fens. Vá Gramr til menja. ${ }^{21}$

The first half-stanza mentions that nobody must bring food and drink to the banquets which were arranged by Sigurðr, because of his generosity. Since the other half-stanza indicates that the earl was regarded as a ruler (protector) of the sanctuary (vés valdr), we may suppose that the first half actually referred to a religious feast, i.e. a blótveizla. The manager and agent of this feast was thus the earl himself. It seems therefore as if Snorri at least had some support in Sigurðardrápa for his account.

It should be noticed that Klaus Düwel's study proceeded on the basis of a new interpretation of this stanza. He interpreted the kenning and designation of Sigurðr, vés valdr, as 'the warrior'.22 According to Düwel, there is nothing supporting an assertion that Snorri knew about ancient traditions of the ritual feasts (blótveizlur) in Trøndelag, he had only support for the idea that Sigurðr was regarded as generous. Skilled philologists, such as Ottar Grønvik and François-Xavier Dillmann have, however, rejected Düwel's attempt and put forward strong arguments in favour of the traditional interpretation of vés valdr as 'the ruler (protector) of the sanctuary'. ${ }^{23}$ Grønvik translated the second part of the stanza as thus: "Hvilken ætling av agefylte (gudfryktige) menn / vil vel strides med (sette seg opp mot) templets herre?" ${ }^{24} \mathrm{He}$ interpreted the problematic word vægja as a hapax legomenon of a noun (gen. pl. of vægir), meaning 'godfearing man, that is, a man who is full of fear (for the deity)' ${ }^{25}$

21 'You do not need to bring with you / neither basket nor tankard / to the generous man. / The gods deceived bjazi. / All men should avoid opposing / the keeper of the sanctuary, / because he makes the chieftains glad. / The ruler battled for the gold' (Heimskringla (Bjarni Aðalbjarnarson 1941-51), 1, p. 168). See also Skjaldedigtning (Finnur Jónsson 1912-15), B 1, pp. 69 f.

22 Most scholars interpret the expression valdr vés as 'the protector of the sanctuary', i.e. 'the ruler Sigurðr'. Klaus Düwel has rejected this interpretation and suggested that the sequence valdr vés vægja should be interpreted as 'der Beherrscher des Thingplatzes der Schwerter' $(=$ Schild $)=$ der Krieger Sigurðr - that is, 'the warrior Sigurðr' (Düwel 1985, pp. 14-17).

23 Norwegian: 'véets (templets, hovets) høvding, hersker' (Grønvik 1989, pp. 82-90). See also Dillmann 1997.

24 'Which offspring of godfearing men, will oppose the ruler of the sanctuary?'

25 Norwegian: 'gudfryktig mann, d.e. mann fylt av vægje, age (for guddommen)'. 
Vægir (nom.) was thus interpreted as a nomen agentis of the verb vægja ('turn aside', 'vike til side'). In my opinion his reasoning for this interpretation is convincing. It seems logical that Snorri based his information about Sigurðr and his generosity at sacrificial feasts on this stanza.

Also other Viking Age skaldic poems may support Snorri's information that Norwegian earls and kings cared for public cult in Trøndelag. According to Vellekla (990), which was quoted by Snorri, ${ }^{26}$ also Earl Hákon Sigurðarson of Hlaðir maintained similar cultic duties as his father. He thus restored the sanctuaries, which had been destroyed by the sons of King Eirikr. It is stated that Hákon "allowed the men of Pórr to uphold the plundered hof-lands and shrines of the gods". ${ }^{27}$ By means of these actions and the cult, which was organized by Hákon, prosperity returned to the country. ${ }^{28} \mathrm{~A}$ similar cultic role is also applied to King Hákon the Good in Hákonarmál, composed around 960. When the king died the skald praised him as follows:

Then it was made known how well that king had protected sanctuaries (byrmt véum) when all those who have domination and power [the gods] bade Hákon welcome. ${ }^{29}$

According to Snorri King Hákon was baptized in England. Towards the end of his life he must have returned to paganism as an apostate, or at least he was taking a more tolerant attitude towards the old religion in Norway. Therefore the skald could praise him in a traditional way, as a ruler who assumed his duties in the cultic sphere, as a protector of public cult and cultic sites. Also this poem was quoted by Snorri. ${ }^{30}$

Snorri had thus also other sources, besides Kormákr's stanza, when writing about the pagan cult in Trøndelag. Some of his sources consisted also of older prose traditions. ${ }^{31}$ Ágrip (AD 1190), for instance, tells us that the Prœndir in Mæri(n) required King Hákon the Good "to sacrifice as other kings used to do or we throw you out of the country, if you do not follow us in this thing". ${ }^{32}$ The story about the horseliver also occurs in this text, but in another version and in much more sparse terms. ${ }^{33}$ Fagrskinna, written sometime between Ágrip and Heimskringla, also reproduces this tradition in short words. At the assembly in Mæri(n)

26 In Haralds saga Gráfeldar (Heimskringla (Bjarni Aðalbjarnarson 1941-51), 1, pp. 198-224).

27 Øll lét senn hinn svinni / sonn Einriða monnum / herjum kunn um herjuð / hofs lond ok vé banda (text and translation Turville-Petre 1976). Cf. Skjaldedigtning (Finnur Jónsson 1912-15), B 1, pp. 117-124.

28 [...] nú grœe jorð sem áðan / aptr geirbrúar hapta / auðrýrir lætr áru / óhryggja vé byggja.

29 Skjaldedigtning (Finnur Jónsson 1912-15), B 1, p. 59.

30 Heimskringla (Bjarni Aðalbjarnarson 1941-51), 1, pp. 193-197.

31 See also Jón Hnefill Aðalsteinsson 1998, pp. 62 ff

32 [...] bádu hann blóta sem aðra konunga í Nóregi, 'ella rekum vér pik af ríki, nema pú gerir nekkvern hlut i sampykki eptir oss' (Ágrip (Bjarni Einarsson 1985), p. 8).

33 [...] at hann biti á hrosslifr, ok svá, at hann brá dúki umb ok beit eigi bera, en blótaði eigi oðrruvís (Ágrip (Bjarni Einarsson 1985), p. 8). 
the people of Trøndelag gave him [King Hákon] two things to choose between. Either he should sacrifice as kings used to do before and in such a way maintain old law/custom for good crops and peace; or else they would throw him out of the country. [...] Because of this threat and out of love for his friends the king yielded to their demands and sacrificed. ${ }^{34}$

The people thus expected that the king must take part in the religious feast and (according to Ágrip) eat the sacrificial meat (i.e. horse liver) in order to become a legitimate king. By means of these rituals he ratified ancient law and (according to Fagrskinna) governed good crops and peace for the people. It seems thus as if he was a necessary ritual link to the gods during these feasts, according to these texts.

\section{Written sources supporting the cultic role of rulers in Eastern Scandinavia}

Snorri's ideas that the pagan rulers in Norway were expected to perform rituals and being involved in public cult were thus not taken from the thin air. He had several sources for these notions. These ideas are actually attested in other parts of Late Viking Age Scandinavia and in other types of sources. Scholion 140 of Adam of Bremen's text, for instance, mentions thus:

Nuper autem cum rex Sueonum christianissimus Anunder sacrificium gentis statutum nollet demonibus offerre, depulsus a regno dicitur a conspectu concilii gaudens abisse, quoniam dignus habebatur pro nomine Iesu contumeliam pati. ${ }^{35}$

According to the context, it seems as if these events took place at the public feast in Uppsala. This scholion indicates thus that the people who gathered in Uppsala during the $11^{\text {th }}$ century still expected that the ruler would perform the great sacrifices, on their behalf. It should be noticed that this scholion appears in the oldest manuscript of Adam's text, namely A2, which usually is dated to about $1100 .{ }^{36}$ It was thus made only 25 years after Adam wrote his text on contemporary conditions in Uppsala.

Similar to Snorri's account on the sacrifices in Trøndelag, aspects of Adam's text, indicate that libation rituals were crucial during these feasts in the 'Uppsala

34 [...] ok á pví pingi gørðu Prœendir konunginum tvá kosti, at hann skyldi blóta eptir vanða enna fyrri konunga ok fylla svá en fornu log til árs ok friðar, elligar mundu peir reka hann af ríkinu, ef hann vildi <eigi> [...] pá gørði hann eptir bœen peira ok blótaði (Fagrskinna (Bjarni Einarsson 1985), p. 80).

35 'When not long ago the most Christian king of the Svear, Anunder, would not offer the demons the prescribed sacrifice of the people, he is said, on being deposed, to have departed from the presence of the council, rejoicing that he had been accounted worthy to suffer reproach for the name of Jesus.' This scholion was probably written by Adam himself, as it occurs in the oldest manuscript A2.

36 Hultgård 1997, pp. 9-15. 
temple'. When Adam described the inner parts of the 'temple' he applied the term triclinium. In classical and mediaeval Latin, this term connotes both 'dining-room' and 'room for ceremonial banquets'. ${ }^{37}$ It is thus quite possible that Adam actually referred to a banqueting hall, when using the term triclinium. ${ }^{38}$ Adam's text supports this explanation further. When describing the sacrifices which took place there he used the verb libo (libare), which may be translated as 'to pour a libation of'. ${ }^{39} \mathrm{He}$ also used the noun libatio in this context, that is, 'a sacrificial offering, especially of drink, libation' and the concept comissatio ('drinking feast, bout').

Adam's description of Uppsala thus indicates several resemblances with Snorri's report. In both accounts royalties are expected to take part in sacrificial rituals, which included ceremonial meals and drinking customs, performed in cultic buildings. Since Snorri probably did not have access to Adam's text, these accounts must be treated as independent sources. ${ }^{40}$ Another possible independent source for these notions from the conversion period is also the tradition about King Ingi Steinkelsson, preserved in the U-version of Hervarar saga (c. 1300), where it says that the Svear removed their king from office, since he would not make sacrifices on their behalf at the assembly which probably was held at Uppsala. It is interesting to notice that the custom of sacrificing horses and eating horse-meat also is crucial in this tradition.

A pingi nockru, er Suiar attu vid Inga kong, giordu peir honum [ij] kosti, huort hann villdi helldur hallda vid ba forn log eda lata aff kongdomi. Pa mællti Ingi kongur og quedst ei mundi kasta peirri tru, sem riett wæri; pa æptu Suiar og preingdu honum med grioti og raku hann aff logpinginu. Sueirn magur kongs var eptir a pinginu; hann baud Suium ad efla bloot fyrir peim, ef peir giæfi honum kongdom. Pui iata peir allir; var Sueirn pa til kongs tekinn yfir alla Suibiod; [ba var] framm leitt hross eitt a pingid og hogguit i sundur og skipt til atz, enn rodid blodinu blottrie. Kostudu ba allir Suiar christni, og hoofust blot; enn peir raku Inga kong a burt, og for hann i vestra Gautland. Blot-Sueirn var iij vetur kongur y fir Suiumm. ${ }^{41}$

37 Dillmann 1997.

38 A Vendel Period hall building has been discovered in Gamla Uppsala, see further below. It cannot be identical with Adam's templum/triclinium, since it disappeared around AD 800.

39 Dillmann 1997.

40 Adam's text was known in medieval Iceland. One passage of it is translated to Old Norse in AM $4154^{\text {to }}$ (c. 1310) and in Flateyjarbók (c. 1390). But Snorri was probably not acquainted with it (cf. Lassen 2011, pp. 122 f.).

41 Hervarar saga (Jón Helgason 1924), p. 160. My translation: 'At the assembly that the Svear held with King Ingi, they gave him two choices. Either he would maintain the ancient law or he had to give up the kingdom. King Ingi said that he was not ready to give up that faith, which was the right one. The Svear shouted and threw stones at him and drove him off the assembly place. Sveinn, the king's brother-in-law, remained at the thing. He told the Svear that he would make sacrifice on their behalf if they would give him the kingdom. All assented to that proposal. Sveinn was taken as king over all Svetjud. A horse was led to the meeting place, dismembered and distributed for eating, and the sacrificial tree was reddened with the blood. All Svear thus abandoned Christianity, re-introduced the sacrifice and drove Ingi off and he travelled to Västergötland. Blótsveinn was king over the Svear for three winters.' 
Because of the change of style, most scholars accept that the chronicle of the Svea-kings has been added to the original version of Hervarar saga. ${ }^{42}$ It may be part of a lost historical source moulded by legendary and mythical elements. Some parts of this tradition are also preserved in Orkneyinga saga, which tells of the Christian King Ingi of Svetjud who fought against paganism. The farmers, however, chose another king, called Blótsveinn (the brother of the Queen) who retained sacrifices. ${ }^{43}$ This tradition may have been transferred to Iceland by Markús Skeggjason, who was probably Ingi's skald before being made Lawman at Pingvellir in $1084 .{ }^{44}$ Blótsveinn's existence has been questioned and his story has been regarded as a medieval exemplum, that is, as a homilectic story. ${ }^{45}$ Yet Blótsveinn (in Old Swedish Blodhsven) is also mentioned independent of Icelandic traditions in "The Legend of St Eskil” (Legenda sancti Eskilli). Here, the sacrifices are said to occur in Strängnäs. ${ }^{46}$

It seems thus, according to these sources, as if the Late Viking Age cult community in Svetjud expected that the king performed or at least participated in the common sacrifice. In my opinion, there is no reason to doubt this information. Perhaps the sacrifice was only valid when the king took part in the rituals. A plausible interpretation is that the king was the most important mediator between the human and the divine world during the sacrifices at this sanctuary. His ritual role in the cult was thus necessary for the society, and per se it also legitimated his high position in other social contexts.

\section{A runic blót-inscription}

Medieval written sources thus support the idea that pagan rulers were involved in the sacrificial feasts in eastern Scandinavia, which included ceremonial meals and drinking rituals. This idea may also be indicated in other types of sources, sources which are undoubtedly pre-Christian. Some runic stones of the Blekinge group may give information about rulers in cultic functions. They were carved not before AD 550 and perhaps not after AD $750 .{ }^{47}$ Stentoften (DaRun 357), Gummarp (DaRun 358) and

42 For instance Schück 1910, pp. 14 f.; Reifegerste 1989, pp. 196-200.

43 Kom pví svá, at bœendr tóku sér annan konung, pann er pá helt til blóta, Sveinn, bróðir drottningar, ok var kallaðr Blót-Sveinn (Orkneyinga saga (Finnbogi Guðmundsson 1965), pp. 90). Snorri was also acquainted with this tradition and mentioned Blót-Sveinn see Heimskringla (Bjarni Aðalbjarnarson 1941-51), 3, S. 263.

44 This theory was first suggested by Henrik Schück 1910, p. 17. Cf. Reifegerste 1989, pp. 198 f.; Sawyer 1991, p. 37; Foote 1993, p. 24.

45 Lönnroth 1996, pp. $150 \mathrm{f}$.

46 Scriptores rerum Suecicarum medii aevi (Fant 1818-76), 2, 1, pp. 391-399

47 On datings of these inscriptions see Runeninschriften (Krause 1966), pp. 203 ff., Moltke 1985 (1976), pp. 137-147. 
Istaby (DaRun 359), have a proper noun HapuwulfR. On Stentoften and Istaby there are also two persons called HariwulfR and HeruwulfR. The Björketorp stone (DaRun 360) can be associated with this group, although it lacks the name HapuwulfR. It has almost exactly the same curse as Stentoften. As the name HabuwulfR appears on three stones in this area scholars believe that he was a local leader in Blekinge at some time around AD $600 .^{48}$

The interpretation of the Stentoften inscription has been debated throughout the $20^{\text {th }}$ century. I have examined it earlier, ${ }^{49}$ and will just refer to Lillemor Santeson's interpretation. She read and interpreted lines 1-3 thus:

\section{niuhAborumR niuhagestumR hApuwolAfRgAfj \\ 'With nine bucks, with nine stallions HabuwulfR gave good growth. ${ }^{50}$}

HapuwulfR performed a sacrifice, where he offered nine bucks and nine stallions. In that way he gave the people a good crop. Perhaps he also arranged a great sacrificial feast at his hall building or at an outdoor-sanctuary, with plenty of meat for all people.

Santeson's interpretation has many advantages compared to previous attempts, and many great runologists such as Henrik Williams, Klaus Düwel and Michael Schulte accept it. ${ }^{51}$ Her interpretation can be supported on several grounds. For instance, the number nine corresponds with the sacrifices at Uppsala and Lejre mentioned by Adam and Thietmar..$^{2}$ As in Uppsala, Lejre and Hlaðir the runic inscription indicates that horses were sacrificed also in Blekinge. ${ }^{53}$ It should also be noticed that the Proto-Nordic word jāra in this inscription probably is equivalent to Old Norse ár appearing in Snorri's text in connection to the sacrifices, meaning 'good crops' ${ }^{54}$

48 E.g. Runeninschriften (Krause 1966), pp. 203-214; Düwel 2008, pp. 21 f.

49 Sundqvist 1997.

50 Santeson 1989 and 1993.

51 Williams 1990, p. 36; Düwel 1992, pp. 348-353; Düwel 2008, pp. 21 f.; Schulte 2006. See also Stoklund 1994, pp. 166-168; Sundqvist 1997; Antonsen 2002. Some scholars have also been sceptical to Santeson, especially regarding the interpretation of the sequence gestumR (see e.g. Reichert 2003). The runologist Michael Schulte (2006) has, however, defended Santeson's interpretations against these recent objections.

52 Gesta Hammaburgensis (Schmeidler 1917), 4, p. 27; Chronicon (Trillmich 1957), 1, p. 17. See Sundqvist 1997, pp. 164-168.

53 Adam writes thus: Corpora autem suspenduntur in lucum, qui proximus est templo. Is enim lucus tam sacer est gentilibus, ut singulae arbores eius ex morte vel tabo immolatorum divinae credantur. Ibi etiam canes et equi pendent cum hominibus, quorum corpora mixtim suspense narravit mihi aliquis christianorum LXXII vidisse (Gesta Hammaburgensis (Schmeidler 1917), 4, p. 27). Thietmar mentions that horses were sacrificed in Lejre: Est unus in his partibus locus, caput istius regni Lederun nomine, in pago, qui Selon dicitur, ubi post VIIII annos mense Ianuario, post hoc tempus, quo nos theophaniam Domini celebramus, omnes convenerunt, et ibi diis suimet LXXXX et VIIII homines et totidem equos, cum canibus et gallis pro accipitribus oblatis, immolant [...]' (Chronicon (Trillmich 1957), 1, p. 17),

54 See Hultgård 1993, 2003 and 2007. 
Stentoften thus supports the idea that a ruler was performing sacrifice, or at least that he commissioned it.

This runic inscription indicates that persons belonging to the top ruling elite were involved in the public cults and perhaps performed ceremonial acts. The changes in sacrificial custom that have been pointed out by archaeologists may reflect changes in social organisation, ${ }^{55}$ from tribal chieftains to 'petty kinglets' and finally more permanent ruling families. The family of HapuwulfR seems to be a dynasty, according to the name customs. ${ }^{56}$ The new ruling elite used religious ceremonies when manifesting their power and sovereignty. They probably institutionalized public cults and tied them to themselves and their residences.

\section{The witness from archaeology}

Snorri's description of cultic leadership in Trøndelag may thus very well be based on old traditions. The notion that the pagan political leader was involved in cultic feasts, and there also took part in some specific rituals, may even reflect Late Iron Age conditions. By means of these rituals he could perhaps also mediate blessings to the people, such as 'good crops'. Most likely these feasts sometimes took place in cultic buildings as Snorri claimed. These ideas can today be attested by archaeology. Underneath the church of Mæri(n), in Inn-Trøndelag, traits of an assumed cultic building from the Viking Age were discovered. ${ }^{57}$ Nineteen (or twenty-three ${ }^{58}$ ) gold foil figures were found in relation to some post-holes, which were considered to be the place of the high-seat. These figures were probably regarded as sacred objects and undoubtedly indicative of rituals performed in the context of the political power of Mæri(n). They were probably produced during the Vendel period, but it has been argued that they still were in use during the Early Viking Age. ${ }^{59}$ At this site also other finds were made which may be associated to pre-Christian ceremonial feastings, such as pieces of pottery and glass, quantities of animal bones and some characteristic cooking stones.

Whether the sanctuary at Mæri(n) was situated on a chieftain farm is somewhat debated. ${ }^{60}$ Viking Age Mæri(n) lacks namely the social and economic criteria typical for the central farms of Trøndelag and it stands out mostly as an exclusive religious site. Most likely the local leaders who cared for the cultic building in Mæri(n) were situated at a farm in the absolute vicinity, perhaps at Egge. This site has a burial

55 See Fabech 1991 and 1994.

56 See Sundqvist / Hultgård 2004.

57 Lidén 1969, 1996 and 1999.

58 Lidén 1999, p. 47.

59 See e.g. Carlie 2004, pp. 174 ff.; Watt 2007, p. 133.

60 See e.g. Stenvik 1996; Røskaft 1997, p. 237; Røskaft 2003, pp. 138 f.; Lidén 1999, p. 45. 
field with rich finds from both Early and Late Iron Age, such as a nice Viking Age sword.

The close relationship between the Prœndir-chieftains, hof-sanctuaries and cultic activities, may also be indicated by archaeological finds attested at farms designated hov in Trøndelag, i.e. places where possibly pre-Christian sanctuaries were erected. ${ }^{61}$ The best example is probably Hove in Åsen, in Strindafylke, where we have great monuments and exclusive finds indicating the presence of political power. ${ }^{62}$ Hove is surrounded by old farms such as Husby and Vang and perhaps they originally constituted one farm unite. All three sites have Viking Age burial fields and at Vang a royal burial mound was erected. The place-name Vang has been interpreted as cultic. ${ }^{63}$ This name may refer to a special kind of cultic meadows, which often was located beside the hof-sanctuaries in pre-Christian Norway (cf. Hovsvangen (Oppl.) and Gudvangen (SogFj)). During excavation at Hove in 1981-84 several finds were made indicating pre-Christian cultic activities. ${ }^{64}$ Several pits with char cool and burned stone suggest that ritual cooking took place there, from Early Iron Age to Late Iron Age. In connection to these pits also post-holes were discovered which not were related to house foundations. Perhaps they could be related to ritual constructions.

Elsewhere in Norway, it is typical that the Iron Age cultic buildings were located at the farms of the rulers and magnates as Snorri intimates. One such building was discovered at the aristocratic farm of Borg, in Lofoten. ${ }^{65}$ At this place five gold foil figures were found in connection to a hall-room (Room C) of a large building (I:1a), over 80 meters long and dated to AD 600-950. These objects were related to the postholes of the high-seat area. The assumed high-seat was located in the north corner of the room, where also a bronze vessel was found as well as two pottery jugs and 18 glass beakers imported from the Continental Europe and the British isles. In this hallroom there were also some unusual fireplace constructions. According to the archaeologists they indicate that ritual cocking took place there during the Early Viking Age. It seems as if this room had two main functions; during most of the year it was an ordinary living room, but on special occasions it functioned as a banqueting hall, where ceremonial meals with drinking rituals were celebrated in the context of the chieftain. Around 950 this house was abandoned.

Archaeological material from Sweden may also support that drinking ceremonies took place at the Iron Age halls of rulers and magnates. Expensive glass fragments have for instance been discovered in connection to the banqueting hall at Helgö (OSw.

61 See Vikstrand 2001; Sundqvist 2009.

62 Farbregd 1986; Røskaft 2003, pp. 66 ff.

63 M. Olsen 1926, p. 218. Cf. Sandnes 1992, pp. 15 f.; Sandnes / Stemshaug 2007, p. 479.

64 Farbregd 1986.

65 See mainly Johanson / Munch 2003; Herschend / Mikkelsen 2003; Munch 2003a and 2003b. 
Hælghø; 'the holy island'), ${ }^{66}$ in the Lake Mälaren. ${ }^{67}$ Interestingly, there was a particular concentration of them at the place interpreted as the 'high-seat', i.e. the place where many gold foil figures also were discovered. The glass was clearly high-status and comprised for instance fragments of cone beakers. It has been estimated that these glass fragments belonged to at least 50 beakers and bowls of different types dated to the period between the Roman Iron Age and the Viking Age. It cannot be excluded that these beakers have been used for ceremonial purposes, for instance in connection to ritual banquets.

In connection to a large Late Iron Age hall building at the farm of Lunda, in Södermanland, there are also finds which may be associated with drinking rituals and ceremonial meals in an aristocratic milieu, such as broken glasses originating from Frankish beakers. ${ }^{68}$ As in Helgö and Borg, some fragments were found close to the assumed high-seat. In connection to this hall three small phallic figures were discovered, which were interpreted as images representing the gods. Two of them were found in a small structure interpreted as a specific cultic house.

At the famous cultic site of Uppsala a hall building was discovered. On Södra Kungsgårdsplatån, just north of the church, post-holes and a stone-construction belonging to a Vendel Period hall $(50 \times 12 \mathrm{~m})$ were found. ${ }^{69}$ Also on the northern plateau (Norra Kungsgårdsplatån) a building was recently excavated. ${ }^{70}$ It was smaller than the hall on Södra Kungsgårdsplatån, but also dated to the Vendel Period. Since the hall at Kungsgården is dated to the Vendel Period and was abandoned in the Early Viking Age, it cannot be identical with the cultic building (templum/triclinium) mentioned by Adam. Post-holes and a stone-packing indicate that a large building also was erected on the spot of the present Romanesque church. A fragment of a mould for a brooch (of the type JP 51), found in the first clay fill under the church, dated to the tenth century, indicates that activities took place there during the Viking Age. ${ }^{71}$ Else Nordahl therefore carefully suggested that the building should be dated to the Viking Age. ${ }^{72}$ Recent excavations indicate that the house is older. ${ }^{73}$

66 In Swedish ‘den heliga (fredade) ön’ (see Vikstrand 2001, pp. 239 ff.).

67 See Herschend 1995 and 1998. For an overview of Helgö in general, see Lamm 1999. See also Vikstrand 2001; Zachrisson 2004a, 2004b and 2011.

68 Andersson 2004; Skyllberg 2008. Cf. Larsson 2011.

69 Nordahl 1996; Gräslund 1997. Scholars have also argued that the last element in the name Uppsala refers to 'banqueting halls' (pl.) (e.g. Brink 1999, pp. 38-39 and 48-49, note 15). New excavations at Old Uppsala in the summer of 2011 indicate that the hall was 50 meter at length.

70 Oral communication from the archaeologist and chief-excavator at Old Uppsala, Hans Göthberg, August 2011 and e-mail J. Ljungkvist, October 2011.

71 Nordahl 1996, p. 63 and 73.

72 Nordahl 1996, pp. 60-62.

73 See Göthberg 2008. 
The traits of large hall buildings in Uppsala are located to the area of the old royal demesne (Kungsgården). ${ }^{74}$ These facts indicate that the ruling power had some kind of influence on these houses and also the activities which took place there. Not far from the royal demesne are also the famous royal grave mounds, dating back to the $6^{\text {th }}$ or $7^{\text {th }}$ century. They were thus situated in an immediate context of the Vendel Period hall at Uppsala and must thus be considered as an element in the sanctuary complex.

The most impressing example of a more exclusive cultic building in an aristocratic context is found at the central place of Uppåkra in Skåne. ${ }^{75}$ This house had first been built during the Roman Iron Age, and was rebuilt at the same spot in several phases up until the Viking Age. It was 13 meters long and probably very high. The size of the posts-holes indicates that. The peculiar finds, for instance, the many gold foil figures, a glass bowl and a gilded silver beaker, also indicate that rituals have taken place there, including drinking ceremonies.

\section{Conclusions}

Several notions of Snorri's description of pre-Christian ceremonial banquets in Hákonar saga góða may thus be attested in other more direct sources, such as skaldic poetry, runic inscriptions and archaeological finds, as well as in Latin texts, written by Christians. For instance, the idea that the political leaders (kings and earls) were involved in public cult may be based on ancient traditions. Snorri was probably also on solid ground when he stated that the rulers (at least the king) were supposed to take part in certain rituals when attending the sacrificial feasts, for instance, the drinking ceremonies and food customs (perhaps eating horse meat). That these ceremonies sometimes took place in some kind of cultic building or banqueting hall as described by Snorri, seems also likely. The list of authentic aspects in his account could perhaps be extended somewhat. We must also emphasize, however, that some elements in his text must be seen with suspicious as noted by Olsen, Walter and Düwel, such as certain religious terms and the action of making the sign of the hammer over the horn. Anyhow, in a general sense, Hákonar saga góða can still be used as a source for preChristian religion, if we treat it with care and use a sound source criticism.

74 Rahmqvist 1986 and 2000.

75 See e.g. Larsson / Lenntorp 2004; Larsson 2011. 


\section{Bibliography}

\section{Sources}

Ágrip af Nóregskonunga sogum. In: Bjarni Einarsson (Ed.) 1985. Fagrskinna. Nóregs konungatal. (Íslenzk fornrit 29). Reykjavík.

Chronicon. In: Trillmich, Werner (Ed.) 1957. Thietmar av Merseburg, Chronik. Thietmari Merseburgensis Episcopi Chronicon. (Ausgewählte Quellen zur deutschen Geschichte des Mittelalters 9). Darmstadt.

Danmarks runeindskrifter. In: Jacobsen, Lis / Moltke, Erik 1942. Danmarks runeindskrifter 1. Text. Copenhagen.

Den norsk-islandske skjaldedigtning. In: Finnur Jónsson (Ed.) 1912-15. Den norsk-islandske skjaldedigtning. 4 volumes. Copenhagen.

Fagrskinna. In: Bjarni Einarsson (Ed.) 1985. Fagrskinna. Nóregs konungatal. (İslenzk fornrit 29). Reykjavík.

Gesta Hammaburgensis Ecclesiae Pontificium. In: Schmeidler, Bernhard (Ed.) 1917. Magistri Adam Bremensis Gesta Hammaburgensis Ecclesiae Pontificium. (Monumenta Germaniae Historica. Scriptores rerum Germanicarum in usum scholarum 7/2). 3. Auflage. Hanover/Leipzig.

Heimskringla. In: Bjarni Aðalbjarnarson (Ed.) 1941-51. Snorri Sturluson. Heimskringla. (Íslenzk fornit 26-28). 3 volumes. Reykjavík.

Hervarar saga. In: Jón Helgason (Ed.) 1924. Heiðreks saga. Hervarar saga ok Heiðreks konungs. (Samfund til Udgivelse af Gammel Nordisk Litteratur 48). Copenhagen.

Historien om Hamburgstiftet. In: Svenberg, Emanuel (Transl.) 1985. Adam Bremensis, Historien om Hamburgstiftet och dess biskopar. Stockholm.

Orkneyinga saga. In: Finnbogi Guðmundsson (Ed.) 1965. Orkneyinga saga. Legenda de sancto Magno. Magnúss saga skemmri. Magnúss saga lengri. Helga páttr ok Úlfs. (İslenzk fornrit 34). Reykjavík.

Runeninschriften. In: Krause, Wolfgang (Ed.) 1966. Die Runeninschriften im älteren Futhark 1. Text. Mit Beiträgen von Herbert Jankuhn. (Abhandlungen der Akademie der Wissenschaften in Göttingen, phil.-hist. Klasse 3/65). Göttingen.

Scriptores rerum Suecicarum medii aevi. In: Fant, Erik Michael (Ed.) 1818-76. Scriptores rerum Suecicarum medii aevi. 3 volumes. Uppsala.

Upplands runinskrifter. In: Wessén, Elias / Jansson, Sven B. F. 1940-58. Sveriges runinskrifter 6-9. Stockholm.

\section{Literature}

Andersson, Gunnar (Ed.) 2004: Att föra gudarnas talan - figurinerna från Lunda. (Riksantikvarieämbetet. Arkeologiska undrsökningar 55). Stockholm.

Antonsen, Elmar H. 2002: Runes and Germanic Linguistics. Trends in Linguistics. (Studies and monographs 149). Berlin/New York.

Baetke, Walter 1950: Die Götterlehre der Snorra-Edda. (Berichte über die Verhandlungen der sächsischen Akademie der Wissenschaften zu Leipzig, phil.-hist. Klasse 97/3). Berlin.

Baetke, Walter 1951: Christliches Lehngut in der Sagareligion. Das Svoldr-Problem. Zwei Beiträge zur Sagakritik. (Berichte über die Verhandlungen der sächsischen Akademie der Wissenschaften zu Leipzig, phil.-hist. Klasse 98/6). Berlin.

Baetke, Walter 1964: Yngvi und die Ynglinger. Eine quellenkritische Untersuchung über das nordische ,Sakralkönigtum '. (Sitzungsberichte der sächsischen Akademie der Wissenschaften zu Leipzig, phil.-hist. Klasse 109/3). Berlin. 
Beck, Heinrich et al. (Eds.) 1968-2008: Reallexikon der Germanischen Altertumskunde. 37 Bände. 2., vollständig neubearbeitete und stark erweiterte Auflage. Berlin/New York.

Brink, Stefan 1999: Fornskandinavisk religion - förhistoriskt samhälle. En bosättningshistorisk studie av centralorter i Norden. In: Drobin, Ulf (Ed.). Religion och samhälle i det förkristna Norden. Et symposium, pp. 11-55. Odense.

Bugge, Sophus 1881-89: Studier over de nordiske Gude- og Heltesagns oprindelse 1. 2 volumes. Christiania.

Carlie, Anne 2004: Forntida byggnadskult. Tradition och regionalitet i södra Skandinavien. (Riksantikvarieämbetet. Arkeologiska undersökningar 57). Stockholm.

Dillmann, François-Xavier 1997: Kring de rituella gästabuden i fornskandinavisk religion. In: Hultgård, Anders (Ed.). Uppsalakulten och Adam av Bremen, pp. 51-73. Nora.

Dillmann, François-Xavier 2008: Omkring Halvdan Svartes gravferd. In: Askedal, John Ole / Myrvoll, Klaus Johan (Eds.). Høvdingen. Om Snorre Sturlasons liv og virke, pp. 73-87. Oslo.

Dumézil, Georges 1948: Loki. Paris.

Düwel, Klaus 1985: Das Opferfest von Lade. Quellenkritische Untersuchungen zur germanischen Religionsgeschichte. (Wiener Arbeiten zur germanischen Altertumskunde und Philologie 27). Wien.

Düwel, Klaus 1992: Runeninschriften als Quellen der germanischen Religionsgeschichte. In: Beck, Heinrich / Ellmers, Detlev / Schier, Kurt (Eds.). Germanische Religionsgeschichte. Quellen und Quellenprobleme, pp. 336-364. (Ergänzungsbände zum Reallexikon der Germanischen Altertumskunde 5). Berlin/New York.

Düwel, Klaus 2008: Runenkunde. 4. edition. Weimar.

Fabech, Charlotte 1991: Samfundsorganisation, religiøse ceremonier og regional variation. In: Fabech, Charlotte (Ed.). Samfundsorganisation og Regional Variation. Norden i romersk jernalder og folkevandringstid, pp. 283-304. (Jysk Arkæologisk Selskabs Skrifter 27). Aarhus.

Fabech, Charlotte 1994: Reading Society from the Cultural Landscape. South Scandinavia between Sacral and Political Power. In: Nielsen, Poul O. / Randsborg, Klavs / Thrane, Henrik (Eds.). The Archaeology of Gudme and Lundeborg, pp. 169-183. Copenhagen.

Farbregd, Oddmunn 1986: Hove i Åsen. In: SPOR - fortidsnytt fra Midt-Norge 2/1986, pp. 42-46. Foote, Peter 1993: Icelandic Historians and the Swedish Image. Comments on Snorri and his Precursors. In: Dahlbäck, Göran (Ed.). Snorre Sturlasson och de isländska källorna till Sveriges historia, pp. 9-42. (Runica et mediævalia, Opuscula 1). Stockholm.

Gräslund, Anne-Sofie 1997: Adams Uppsala - och arkeologins. In: Hultgård, Anders (Ed.). Uppsalakulten och Adam av Bremen, pp. 101-115. Nora.

Grønvik, Ottar 1989: Kormaks vers om Sigurd jarls blot. In: Eithun, Bjørn (Ed.). Festskrift til Finn Hødnebø 29. desember 1989, pp. 82-90. Oslo.

Göthberg, Hans 2008: Bosättning och kyrkogård vid Gamla Uppsala kyrka. Uppsala.

Hedeager, Lotte 2011: Iron age Myth and Mentality. An Archaeology of Scandinavia AD 400-1000. London/New York.

Herschend, Frands 1995: Hus på Helgö. In: Fornvännen 90, pp. 221-228.

Herschend, Frands 1998: The Idea of the Good in Late Iron Age Society. (Occasional Papers in Archaeology 15). Uppsala.

Herschend, Frands / Kaldal Mikkelsen, Dorthe 2003: The main building at Borg (I:1). In: Munch, Gerd Stams $\varnothing$ (Ed.). Borg in Lofoten A chieftain's farm in North Norway, pp. 41-76. Trondheim.

Holtsmark, Anne 1964: Studier i Snorres mytologi. (Skrifter utg. av Det Norske Videnskaps-Akademi i Oslo, hist.-filos. Klasse. Ny Serie 4). Oslo.

Hultgård, Anders 1993: Altskandinavische Opferrituale und das Problem der Quellen. In: Ahlbäck, Tore (Ed.). The Problem of Ritual, pp. 221-259. (Scripta Instituti Donneriani Aboensis 15). Stockholm. 
Hultgård, Anders 1996: Fornskandinavisk kult - finns det skriftliga källor? In: Engdahl, Kerstin / Kaliff, Anders (Eds.). Religion från stenålder till medeltid, pp. 25-57. (Riksantikvarieämbetet. Arkeologiska undersökningar 19). Linköping.

Hultgård, Anders 1997: Från ögonvittnesskildring till retorik. Adam av Bremens notiser om Uppsalakulten i religionshistorisk belysning. In: Hultgård, Anders (Ed.). Uppsalakulten och Adam av Bremen. Nora.

Hultgård, Anders 2003: Ár - ,Gutes Jahr und Ernteglück‘. Ein Motivkomplex in der altnordischen Literatur und sein religionsgeschichtlicher Hintergrund. In: Heizmann, Wilhelm / van Nahl, Astrid (Eds.). Runica - Germanica - Mediaevalia, pp. 282-308. (Ergänzungsbände zum Reallexikon der Germanischen Altertumskunde 37). Berlin/New York.

Hultgård, Anders 2007: Kultens språk - rituella formler och rituell åkallan i fornskandianvisk religion. In: Nordgren, Ingemar (Ed.). Kult, guld och makt - ett tvärvetenskapligt symposium i Götene, pp. 123-132. (Historieforum Västra Götaland, series B, vetenskapliga rapporter och småskrifter 4). Göteborg.

Johanson, Olav Sverre / Munch, Gerd Stams $ø$ (2003): Introduction and summary. In: Munch, Gerd Stams $\varnothing$ (Ed.). Borg in Lofoten. A chieftain's farm in North Norway, pp. 11-18. Trondheim.

Jón Hnefill, Aðalsteinsson 1998: A Piece of Horse Liver. Myth, Ritual and Folklore in Old Icelandic Sources. Reykjavík.

Jónas, Kristjánsson 1988: Eddas and Sagas. Iceland's Medieval Literature. Reykjavík.

Lamm, Kristina 1999: Helgö. §§ 2-5. In: Beck et al. (Hrsg.) 1968-2008, 14, pp. 286-291.

Larsson, Lars 2011: A ceremonial building as a 'home of the gods'? In: Grimm, Oliver / Pesch, Alexandra (Eds.). The Gudme/Gudhem Phenomenon, pp. 189-206. Neumünster.

Larsson, Lars / Lenntorp, Karl-Magnus (2004): The Enigmatic House. In: Larsson, Lars (Ed.). Continuity for Centuries. A Ceremonial Building and its Context at Uppåkra, Southern Sweden, pp. 3-48. (Uppåkrastudier 10). Stockholm.

Lassen, Annette 2011: Odin på kristent pergament. En teksthistorisk studie. Copenhagen.

Lidén, Hans-Emil 1969: From Pagan Sanctuary to Christian Church. The Excavation of Mære Church in Trøndelag. In: Norwegian Archaeological Review 2, pp. 3-32.

Lidén, Hans-Emil 1996: Utgravning i Mære kirke. Hvordan skal funnene tolkas. In: Walberg, Øystein (Ed.). Før og etter Stiklestad 1030. Religionsskifte - kulturforhold - politisk makt. Seminar på Stiklestad, 1994, pp. 59-68. Verdal.

Lidén, Hans-Emil 1999: En gullgubbe. Festskrift til Hans-Emil Lidén. Øvre Ervik.

Lönnroth, Lars 1996: En fjärran spegel. Västnordiska berättande källor om svensk hedendom och om kristningsprocessen på svenskt område. In: Nilsson, Bertil (Ed.). Kristnandet i Sverige. Gamla källor och nya perspektiv, pp. 141-158. (Projektet Sveriges kristnande 5). Uppsala.

Meulengracht Sørensen, Preben 1991: Håkon den gode og guderne. Nogle bemærkninger om religion og centralmagt i det tiende århundrede - og om religionshistorie og kildekritik. In: Mortenssen, Peder / Rasmussen, Birgit (Eds.). Fra Stamme til Stat i Danmark 2. Høvdingesamfund of kongemagt, pp. 235-244. Århus.

Mogk, Eugen 1923: Novellistische Darstellung mythologischer Stoffe Snorris und seiner Schule. (Folklore Fellows Communications 51). Helsinki.

Mogk, Eugen 1932: Zur Bewertung der Snorra-Edda als religionsgeschichtliche und mythologische Quelle des nordgermanischen Heidentums. (Berichte über die Verhandlungen der Sächsischen Akademie der Wissenschaften zu Leipzig, phil.-hist. Klasse 84/2). Leipzig.

Moltke, Erik 1985: Runes and their Origin. Denmark and Elsewhere. Copenhagen.

Munch, Gerd Stams $\varnothing 2003 a$ : Jet, amber, bronze, silver and gold artefacts. In: Munch, Gerd Stams $\varnothing$ (Ed.). Borg in Lofoten. A chieftain's farm in North Norway, pp. 241-252. Trondheim.

Munch, Gerd Stams $\varnothing 2003 \mathrm{~b}$ : Borg as a pagan centre. In: Munch, Gerd Stams $\varnothing$ (Ed.). Borg in Lofoten. A chieftain's farm in North Norway, pp. 253-263. Trondheim. 
Nordahl, Else 1996: ... templum quod Ubsola dicitur ... i arkeologisk belysning. (Aun 22). Uppsala. Olsen, Magnus 1926: Attegård og helligdom: Norske stednavn sosialt og religionshistorisk belyst. (Instituttet for sammenlignende kulturforskning, serie A: Forelesninger 9A). Oslo.

Olsen, Olaf 1966: Hørg, hov og kirke. Historiske og arkæologiske vikingetidsstudier. Copenhagen. Rahmqvist, Sigurd 1986: Gamla Uppsala by - Upplands största. In: Nevéus, Torgny / Cnattingius, Nanna (Eds.). Från Östra Aros till Uppsala. En samling uppsatser kring det medeltida Uppsala, pp. 254-271. (Uppsala stads historia 7). Uppsala.

Rahmqvist, Sigurd 2000: Gamla Uppsala under medeltiden. In: Friberg (Ed.). Myt, makt och människor. Tio uppsatser om Gamla Uppsala, pp. 47-49. Stockholm.

Reichert, Hermann 2003: Vier Miszellen zum Urgermanischen und ,Altrunischen‘. In: Zeitschrift für deutsches Altertum und deutsche Literatur 132, pp. 335-356.

Reifegerste, E. Matthias 1989: Die Hervarar Saga. Eine kommentierte Übersetzung und Untersuchungen zur Herkunft und Integration ihrer Überlieferungsschichten. (Altnordische Bibliothek 6). Cologne/Leverkusen.

Røskaft, Merete 1997: Kultkontinuitet og tidlig kirkebygging i Trøndelag. In: Rumar, Lars (Ed.). Helgonet ui Nidaros. Olavskult och kristnande i Norden, pp. 224-239. Stockholm.

Røskaft, Merete 2003: Maktens landskap. Sentralgårdar i Trøndelag ved overgangen fra vikingtid til kristen middelalder, ca. 800-1200. (Skriftserie fra Historisk institutt 39). Trondheim.

Sandnes, Jørn 1992: Haupttypen sakraler Ortsnamen Westskandinaviens Anhang: Karte der sakraler Ortnamen in Rogaland (,Stavanger Amt' nach M. Olsen). In: Hauck, Karl (Ed.). Der historische Horizont der Götterbild-Amulette aus der Übergangsepoche von der Spätantike zum Frühmittelalter, pp. 257-265. (Abhandlungen der Akademie der Wissenschaften in Göttingen, phil.-hist. Klasse, 3/200). Göttingen.

Sandnes, Jørn / Stemshaug, Ola 2007: Norsk stadnamnleksikon. Oslo.

Santesson, Lillemor 1989: En blekingsk blotinskrift. En nytolkning av inledningsraderna på Stentoftenstenen. In: Fornvännen 84, pp. 221-229.

Santesson, Lillemor 1993: Eine Blutopferinschrift aus dem südschwedischen Blekinge. Eine Neudeutung der einleitenden Zeilen des Stentoften Steines. In: Frühmittelalterliche Studien 27, pp. 241-252.

Sawyer, Peter H. 1991: När Sverige blev Sverige. (Occasional Papers on Medieval Topics 5). Alingsås.

Schjødt, Jens Peter 2008: Initiation Between Two Worlds: Structure and Symbolism in Pre-Christian Scandinavian Religion. (The Viking Collection 17). Odense.

Schück, Henrik 1910: Sveriges förkristna konungalängd. (Uppsala universitets årsskrift 1910/6). Uppsala.

Schulte, Michael 2006: Ein kritischer Kommentar zum Erkenntnisstand der Blekinge Inschriften. In: Zeitschrift für deutsches Altertum und deutsche Literatur 135, pp. 399-412.

Skyllberg, Eva 2008: Gudar och glasbägare - järnåldersgården i Lunda. In: Gestalter och gestaltningar. Om tid, rum och händelser i Lunda. (Riksantikvarieämbetet. Arkeologiska undersökningar 72). Stockholm.

Steinsland, Gro 2000: Den hellige kongen. Om religion og herskermakt fra vikingtid til middelalder. Oslo.

Steinsland, Gro 2005: Norrøn religion. Myter, riter, samfunn. Oslo.

Stenvik, Lars F. 1996: Gravminner og maktsentra. In: Walberg, Øystein (Ed.). Før og etter Stiklestad 1030. Religionsskifte - kulturforhold - politisk makt. Seminar på Stiklestad, 1994, pp. 79-92. Verdal.

Stoklund, Marie 1994: Myter, runer og tolkning. In: Schjødt, Jens Peter (Ed.). Myte og ritual i det førkristne Norden. Et Symposium, pp. 159-174. Odense.

Ström, Åke V. 1975: Germanische Religion. In: Ström, Åke V. / Biezais, Haralds (Eds.). Germanische und Baltische Religion, pp. 15-306. (Die Religionen der Menschheit 19/1). Stuttgart u.a. 
Sundqvist, Olof 1997: Runology and History of Religions. Some Critical Implications of the Debate on the Stentoften Inscription. In: Elmevik, Lennart / Peterson, Lena (Eds.). Blandade runstudier 2, pp. 135-174. (Runrön 11). Uppsala.

Sundqvist, Olof 2009: The question of ancient Scandinavian cultic buildings: with particular reference to Old Norse hof. In: Temenos 45, pp. 275-294.

Sundqvist, Olof / Hultgård, Anders 2004: The Lycophoric Names of the $6^{\text {th }}$ to $7^{\text {th }}$ Century Blekinge Rune Stones and the Problem of their Ideological Background. In: van Nahl, Astrid / Elmevik, Lennart / Brink, Stefan (Eds.). Namenwelten. Orts- und Personennamen in historischer Sicht, pp. 583-602. (Ergänzungsbände zum Reallexikon der Germanischen Altertumskunde 44). Berlin/New York.

Turville-Petre, Edward Oswald Gabriel 1976: Skaldic Poetry. Oxford.

Vésteinn, Ólason 1998: Dialogues with the Viking Age. Narration and Representation in the Sagas of the Icelanders. Reykjavík.

Vikstrand, Per 2001: Gudarnas platser. Förkristna sakrala ortnamn i Mälarlandskapen. (Acta academiae regiae Gustavi Adolphi 77. Studier till en svensk ortnamnsatlas utgivna av Thorsten Andersson 17). Uppsala.

Walter, Ernst 1966: Quellenkritisches und Wortgeschichtliches zum Opferfest von Hlaðir in Snorris Heimskringla (Hák. gód. c. 17). In: Rudolph, Kurt (Ed.). Festschrift Walter Baetke. Dargebracht zu seinem 80. Geburtstag am 28. März 1964, pp. 359-367. Weimar.

Watt, Margareta 2007: Kan man tyde guldgubbernes gestussprog? In: Nordgren, Ingemar (Ed.). Kult, guld och makt - ett tvärvetenskapligt symposium i Götene, pp. 133-148. (Historieforum Västra Götaland, series B, vetenskapliga rapporter och småskrifter 4). Göteborg.

Weibull, Curt 1964: Om det svenska och det danska rikets uppkomst. In: Weibull, Curt (Ed.). Källkritik och historia. Norden under äldre medeltiden, pp. 7-52. Stockholm.

Weibull, Lauritz 1948: Nordisk historia. Forskningar och undersökningar 1. Forntid och vikingatid. Stockholm.

Williams, Henrik 1990: Åsrunan. Användning och ljudvärde i runsvenska steninskrifter. (Runrön 3). Uppsala.

Williams, Henrik 1996: Vad säger runstenarna om Sveriges kristnande? In: Nilsson, Bertil (Ed.). Kristnandet i Sverige. Gamla källor och nya perspektiv, pp. 45-83. (Projektet Sveriges Kristnande 5). Uppsala.

Zachrisson, Torun 2004a: Det heliga på Helgö och dess kosmiska referenser. In: Andrén, Anders / Jennbert, Kristina / Raudvere, Catharina (Eds.). Ordning mot kaos - studier av nordisk förkristen kosmologi, pp. 343-388. (Vägar till Midgård 4). Lund.

Zachrisson, Torun 2004b: The Holiness of Helgö. In: Gyllensvard, Bo (Ed.). Excavations at Helgö XVI. Exotic and Sacral Finds from Helgö, pp. 143-175. Stockholm.

Zachrisson, Torun 2011: Helgö - mer än ett vi. In: Bratt, Peter / Grönwall, Richard (Eds.). Makt, kult och plats. Rapport från arkeologiska seminarier vid Stockholms läns museum, pp. 79-88. Stockholm. 